\title{
Personal and Environmental Factors that Influence the Ecological Behaviour of Energy-Efficient Appliance Purchases
}

\author{
Sai-Keong Chan ${ }^{\mathrm{a}}$, Farzana Quoquab ${ }^{\mathrm{b}}$ \& Rohaida Basiruddin ${ }^{\mathrm{c}}$
}

\begin{abstract}
This study investigates the effects of personal and environmental factors on ecological beliefs and ecological behaviour and assesses the mediating and moderating influences in this model. This study utilises 592 questionnaire surveys among Malaysian consumers. A partial least squares technique (PLS) was utilised to analyse the data and to test the study hypotheses. The findings show that personal and environmental factors have a positive influence on ecological beliefs and ecological behaviour; ecological beliefs are positively related to ecological behaviour. Additionally, ecological beliefs mediate the relationship between personal factors and ecological behaviour, and the relationship between environmental factors and ecological behaviour. The present study is among the pioneers in including environmental factors and ecological beliefs in pro-environmental studies. In the context of energy-efficient appliance purchases, the findings elaborate on the existing knowledge of personal and environmental factors, and individual's beliefs.
\end{abstract}

Keywords: Ecological behaviour; Ecological beliefs; Social influences; Facilitating conditions; Ecoaltruistic values; Openness to change.

JEL Classification: M21, M31

\section{Introduction}

Electrical energy is the most convenient and widely used energy in the world. Electricity is used by industry as the input for conversion processes and also by households to improve their living status. As such, the demand and usage of electricity in many countries is growing faster

a Corresponding author. Faculty of Business, Information and Human Sciences, Infrastructure University Kuala Lumpur, Selangor, Malaysia.Email: csk@iukl.edu.my

b Azman Hashim International Business School, Universiti Teknologi Malaysia, Kuala Lumpur, Malaysia.Email:fqbhabib@ibs.utm.my

c Azman Hashim International Business School, Universiti Teknologi Malaysia, Kuala Lumpur, Malaysia.Email: rohaida@ibs.utm.my 
than its production rate (Khan \& Halder, 2016). Such a situation has led to an increasing interest in, and greater development of electrical energy conservation. Energy conservation is the effort made to reduce the consumption of energy by using less of an energy service (Steg, 2008). Electrical energy can be conserved by improving efficiency through technological upgrades in household appliances. It is increasingly recognised that strategies for changes in behaviour are more effective at the household level than at the industry level (Khan \& Halder, 2016).

Electrical energy conservation programmes begin with the offerings of energy-efficient appliances in the hope that consumers can replace the old appliances with new ones. A careful selection of the types of appliances to be purchased by consumers is crucial for the success of energy conservation programmes (Nilsson, Wester, Lazarevic \& Brandt, 2018). Replacing traditional appliances is not just about saving money, it is also about contributing towards the protection of the environment (Guckian, Young $\&$ Harbo, 2017). For example, replacing an old refrigerator with a highefficiency model can reduce energy consumption by 1050 kilowatt hours (kWh) (approximately RM481.25) and carbon dioxide (CO2) emissions by 100 kilograms $(\mathrm{kg})$ per year (Mahlia \& Saidur, 2010).

There are many ways to contribute to the creation of a sustainable environment. As a consumer, wisely choosing environmentally friendly products could be a small way to contribute towards protecting the environment. For instance, purchasing energy-efficient appliances is a way of contributing towards a greener planet. Not only do the purchase and use of 'green' appliances help in reducing utility costs; it also plays a part in protecting the environment, which will be inherited by future generations. Such changes at the consumer and household levels are crucial as it is difficult to execute energy efficiency programmes in other sectors (Cherry, Hopfe, MacGillivray \& Pidgeon, 2017).

The study of ecological behaviour from a social-psychological perspective mainly involves the value-belief-norm (VBN) theory developed by Stern (2000). This model posits that value and belief components are the predictors of ecological behaviour. In short, the personal values and beliefs towards the environment are the central factors in the adoption of ecological behaviour. These personal influences are evident in many previous studies (Chan, Quoquab \& Rohaida, 2018; Chou, 2014; Huang, 2016; Raineri \& Paille, 2016). 
Many studies have mentioned that values are the ultimate predictors of ecological behaviour (Stern, 2000; Schultz \& Zelezny, 1999). Hence, values can be regarded to be the basis that forms and influences human behaviour. Generally, researchers are only focused on internal (individual) factors when studying ecological behaviour (Fraj \& Martinez, 2007; Wu, DiGiacomo \& Kingstone, 2013). Studies focusing on external factors are limited. It makes sense for human behaviour to inevitably require a multi-dimensional view, which incorporates both internal and external elements (Bandura, 1997). As such, external situational factors should be included in the study of ecological behaviour as a whole, instead of just as a sum of their parts.

According to Stern (2000), people tend to consider the implications of their behavioural choices before carrying out the actual behaviour, especially when it concerns things that they value. Hence, environmental attitudes or beliefs can be considered to be important antecedents of environmental behaviour. However, this value-belief relationship has not been measured or tested directly in many studies. Even in the VBN theory, the relationship between values and beliefs was not measured and tested directly (Steg, Dreijerink \& Abrahamse, 2005). The belief variables are represented by three variables, which are ecological worldview (NEP), adverse consequences for valued objects $(\mathrm{AC})$ and perceived ability to reduce threat (AR). This makes the situation more complex, and measuring a person's belief becomes complicated. As such, a simpler approach in dealing with this construct is desired.

Realising the benefits provided by energy-efficient appliances, consumers are supposed to be more likely to purchase them without any hesitation. But in reality, the use of energy-efficient appliances in Malaysia remains at an unsatisfactory level as many consumers are not replacing their household appliances with energy-efficient ones (Tan, Ooi \& Goh, 2017). Human beliefs about the consequences of an individual's action do not directly drive behaviour (Kollmuss \& Agyeman, 2002). Due to this, factors that moderate the normal relationship between ecological belief and ecological behaviour should be included in the study. Moreover, such ecological behaviour is not mandatory and is very much based on the individual's willingness to do so.

Based on the above discussion, the present study aims: first, to investigate the effects of personal values (ecoaltruistic and openness to change values) and environmental factors (social influences and facilitating 
conditions) on ecological beliefs and ecological behaviour; second, to examine the direct relationship between ecological beliefs and ecological behaviour; third, to assess the mediating role of ecological beliefs in the relationship between personal values and ecological behaviour and between environmental factors and ecological behaviour; and fourth, to assess the moderating role of voluntariness in the relationship between ecological beliefs and ecological behaviour.

Thus far, there are not many studies that deal with or investigate the direct relationships between ecological values, ecological beliefs and ecological behaviours. By filling this research gap, this study is contributing to the body of knowledge by directly evaluating the new relationships between these variables. Another contribution of this study is the inclusion of the mediator and moderator in the research model. As discussed above, whenever new direct relationships between value-belief-behaviour were observed, this study also examined the mediating effect of ecological beliefs between personal factors and ecological behaviours, and between situational factors and ecological behaviours. Such an inclusion of the mediating effect is considered to be very rare in this type of study.

This paper is organised as follows: First, an overview of the research background is provided. Next, the relevant literature is reviewed, and a conceptual framework is proposed. Third, the research methodology and results are presented, and this is followed by a discussion of the findings. Finally, the conclusion, managerial implications and suggestions for future research are detailed.

\section{Literature Review}

\subsection{Underpinning theories}

This study utilises the VBN theory, Unified Theory of Acceptance and Use of Technology (UTAUT) and Cognitive Behavioural Theory (CBT) to support the conceptual framework developed in this study. The VBN theory posits that personal values and beliefs towards the environment were found to be influencing various pro-environmental behaviours (Chua, Quoquab, Mohammad \& Basiruddin, 2016; Chou, 2014; Huang, 2016). Thus, belief is considered an important antecedent of ecological behaviour (Lopez \& Arango, 2008; Stern, Dietz, Abel, Guagnano \& Kalof., 1999). According to 
Stern (2000), the VBN is considered a well-known theory used in the study of ecological behaviour. The VBN theory is being studied and tested in many environmental-related studies. There are researchers who have both adopted and tested the whole model (Steg et al., 2005) and also some components of the model (Kaiser, Hubner \& Bogner, 2005; Nordlund \& Garville, 2003) in their studies.

UTAUT is a widely used theory in explaining the users' intention and usage behaviour of a particular new technology (Chen \& Li, 2010; Ramayah, 2010; Venkatesh, Morris, Davis \& Davis, 2003; Yu, 2014) Since this study is also pertaining to technology acceptance, UTAUT has proven to be better in explaining the variance and is being adopted for a clearer picture on the external environment influence (Johnstone \& Hooper, 2016). This theory incorporates both internal and external factors in explaining the new technology usage behaviour ( $\mathrm{Yu}, 2014)$ that is appropriate to be applied in this study. This theory helps in connecting the situational influences towards human behaviour.

CBT is a theory that is rooted around three components: cognitive, emotional and behavioural. In the CBT model, cognitive processes (in the form of judgments or assumptions) are the primary determinants of one's feelings and beliefs in response to a situation (Cigno \& Bourn, 1998). From this perspective, people do not just react emotionally, instead, the thinking component mediates the way that people respond to environmental cues (Beck, 1979). Such cognitions can be intentionally modified and changed (Neenan, 2018). In a study pertaining to the behavioural intervention on prisoners, Walters (2017) revealed that prisoners who displayed a drop in criminal thinking scores between pre-test and post-test levels are more likely to show a reduction in prison misconduct and vice versa. This theory helps to link the mediating effect of voluntariness towards the belief-behaviour relationship.

\subsection{Ecological behaviour}

Behaviour is the way in which a person acts in response to a particular situation or stimulus. For instance, if a person thinks that driving a car will cause air pollution (due to $\mathrm{CO} 2$ emission), he or she will likely reduce their usage or use more public transport in their daily life. Such an action or behaviour is referred to as ecological behaviour, which is intended to protect 
and to reduce negative impacts towards the environment. There are various similar terms used interchangeably in describing ecological behaviour, such as green behaviour, pro-environmental behaviour, social behaviour and environmental action.

Ecological behaviour basically refers to those actions that contribute towards environmental preservation and/or conservation (Axelrod \& Lehman, 1993). Environmental preservation is the attempt to keep the natural environment in its original form, whereas environmental conservation is to protect the natural environment against pollution and human destruction. According to Stern (2000), ecological behaviour refers to the activities intended to protect the environment or to reduce its deterioration on the environment itself. Basically, ecological behaviours are those behaviours that consciously seek to minimise the negative impact of one's actions on the natural and built world (Kollmuss \& Agyemen, 2002). This terminology has been conceptualised in different ways throughout the decades (Sanchez, Mosquera \& Lopez, 2016).

Since the present study context is related to the issue of energy efficiency, the operational definition of ecological behaviour here refers to those actions by individual consumers of purchasing appliances equipped with energy-saving features. Besides, the consumers are also interested in learning and participating in energy efficiency-related issues and events.

\subsection{Ecological belief}

Environmental studies have focused on the ecological beliefs; understanding these as being the result of a rational cost-benefit analysis derived from environmental behaviour (Stern, 2000). Lopez and Arango (2008) explain that ecological beliefs refer to the beliefs about the relationship between human beings and the environment, as well as the consequences of ecological protection or deterioration based on personally-valued aspects. It is clearly seen that ecological beliefs refer to the human-environmental relationship (Stern, 2000). Whereas O'Connor, Bord and Fisher (1999) define ecological beliefs as a sense of awareness and obligation that provide cues for appropriate environmental behaviour, ecological beliefs can be represented by individual risk perception towards the environment (Schwarz \& Thompson, 1990).

To suit this study context, the ecological beliefs are operationalised as 
consumers' beliefs about the relationship between the excessive wastage of electrical energy by both individuals and industries and its impacts on society.

\subsection{Environmental factors}

In the marketing literature, it is very common to suggest that external factors exert an influence on consumer behaviour. 'External factors' is a broad concept that covers many perspectives. 'Environmental factors' appear to be narrower in scope, referring to the situations where a person is encountered with issues relating to the environment, especially in the retail industry (Ibrahim \& Harrison, 2019). Hence environmental factors are considered as a more appropriate scope for this study.

Donovan and Rossiter (1982) suggest that consumer behaviour in retail stores is primarily an emotional response to the factors making up the retail environment. As such, consumer behaviour is not solely based on internal factors (for example, personality, culture and social influences), environmental factors must also be taken into consideration. In the decisionmaking process, consumers are surrounded by environmental factors that influence their purchasing decisions (Bues, Steiner, Stafflage \& Manfred, 2017). Some of these factors are constants, while some are more situational in nature. For instance, shopping with someone else can affect the types of products that a person will look at, or even the price level of the products that they may consider.

Since the present study is focused on the adoption and usage of energy-efficient appliances, it is quite similar to the context of technology acceptance. Davis (1989) describes technology acceptance as a user's decision about how and when they will use technology. More specifically, this study is looking into the purchase and usage of energy-efficient appliances, and thus, the related theories are reviewed to borrow and to adopt the environmental factors/variables for this study.

The UTAUT was proposed by Venkatesh et al. (2003) by compositing the eight prominent theories and models. According to this theory, there are four critical factors that drive usage intention and usage behaviour of a technology. These critical factors are: performance expectancy, effort expectancy, social influences and facilitating conditions (Venkatesh et al., 2003). Social influences and facilitating conditions are the additional 
environmental factors to UTAUT to predict usage intention and usage behaviour. Social influences relate to the degree to which an individual perceives it to be important that others believe he or she should or should not perform the behaviour in question (Venkatesh et al., 2003). Social factors such as religion, family and friends are constantly affecting human beings' decisions and lifestyles. Social influence is the change in behaviour that one person causes in another. A person's decision sometimes is influenced by others. The decision of purchasing and using energy-efficient appliances is also affected by others. Those influencers could be those who are important and close to the consumers.

Facilitating conditions relate to the degree to which an individual believes that an organisational and technical infrastructure exists to support use of the system (Venkatesh et al., 2003). A facilitating condition is the belief of the existence of aspects and resources that will assist users in using a new system. It refers to users' perception about the presence of control factors that might facilitate or hinder their performance of the behaviour (Rahmat \& $\mathrm{Au}, 2013$ ). There are also environmental or situational factors that influence a person's decision. Such influencing factors can be provided by governments, business organisations or non-profit organisations. It refers to the consumers' belief that factors in the environment that make for the purchase and usage of energy-efficient appliances are easy to accomplish.

Additionally, voluntariness of use is posited to moderate the relationship between usage intention and behaviour. Voluntariness refers to the extent to which potential adopters perceive the adoption decision to be nonmandatory (Venkatesh et al., 2003). In general, voluntariness is defined as a choice without restriction and cogitative in helping actions through formal institutions, without anticipation of any benefits (Snyder \& Omoto, 2008). It was included by Moore and Benbasat (1991) as a determinant of usage behaviour. It refers to the extent to which the decision to purchase and to use any energy-efficient appliances is to gain its real benefits instead of being forced or required by others.

Since the context of study is very much similar, the social influences, facilitating conditions and voluntariness are adopted and included as the environmental factors in the research framework. 


\subsection{Personal values}

Recent environmental-related studies that focus on values are normally based on the work of Schwartz (1992) and Stern and Dietz (1994). Schwartz (1992, p.21) defines a value as: "a desirable trans situational goal varying in importance, which serves as a guiding principle in the life of a person or other social entity." Values are the guiding principle for selecting behaviour and events. Values are in a system of priorities. This feature implies that when different competing values are activated in a specific situation, choices are based on values that are considered to be most relevant to act on. According to Rokeach (1973), human values are representations of cognitive and processing needs, with a view to identifying and predicting how the subject would behave in different situations. Torelli and Kaikati (2009) believe that the values direct the behaviour of people and can be related to specific focuses of functioning, as well as form interrelated structures. Basically, those who have a high level of environmental concern are those who are concerned about environmental problems and dangers to the earth's ecosystems and to its natural sustainability (Schultz, 2000).

There are many empirical studies that found this value-behaviour relationship to be significant. Kaiser, Wolfing and Fuhrer's (1999) study on the intention to behave ecologically reveal that personal environmental values are positively related to ecological behaviour. Attitudinal variables (both environmental and social values) are found to be significantly correlated with ecological behaviour. This relationship was proven in both Gatersleben, Murtagh and Abrahamse's (2014) and Gonzalez, Felix, Carrete, Centena and Castano's (2015) studies that examine the role of value in explaining the ecological behaviour. This means that the values direct the people's behaviour.

Schwartz's $(1992,1994)$ universal value system is commonly used in many previous environmental studies. These studies have theoretically reasoned and empirically validated that values play a significant role in explaining ecological beliefs and ecological behaviour (Nordlund \& Garvill, 2003; Schultz \& Zelezny, 1999; Stern et al., 1999). Schwartz's (1992) universal value system comprises 56 general value classifications, which can be divided into 10 motivational types of values based on individual level analysis. These 10 value types can be plotted into two major dimensional spaces. Sometimes, these value systems are referred to as bipolar values 
systems. The dimensions are a) openness to change and conservation; and b) self-transcendence and self-enhancement.

Self-transcendence or ecoaltruistic values refer to those environmental attitudes regarded as feelings of moral obligation to behave in a way which benefits other human beings (Lopez \& Arango, 2008, p. 624). Basically, those who have a high level of environmental concern are those who believe the ecological environment and its conditions will affect different valued aspects, to others and to nature (Schultz, 2000). It refers to the environmental values pertaining to the relationship between humankind and natural resources. Those who have a high level of ecoaltruism are those consumers who believe that defending and protecting all resources is necessary so as to advantage other social beings. Specifically, the ecoaltruistic values have been linked to ecological behaviour. For instance, Karpudewan, Ismail and Roth's (2012) study of 110 Malaysian pre-service chemistry teachers find that ecoaltruistic values are related to environmental behaviour. LopezMosquera and Sanchez (2012) state that ecological values influence the general environmental beliefs. Their study analysed 194 visitors to a suburban Spanish park on their willingness to pay for park conservation.

Openness to change generally refers as a person's inherent mind and character to be imaginative, nonconforming and unconventional (Judge, Bono, Ilies \& Gerhardt, 2002). This disposition or state of mind will influence a person's behaviour. Innovativeness (the degree to which an individual adopts a new idea or an innovation) is one of the components that will impact adoption decisions (Rogers, 2003). If a person has a high level of innovativeness, their adoptions of new ideas will be earlier or faster than those with a low level of innovativeness (Choi, Kim \& Lee, 2010). Basically, this refers to the consumers' level of acceptance and conscious awareness of the implementation and usage of energy-efficient appliances.

\section{Conceptual Framework and Hypotheses}

UTAUT is a theory that helps in connecting the situational influences towards human behaviour. Social influences have an impact on various behaviours as found in many previous studies. For instance, Harman and Koivisto's (2015) study on the social influences on exercise practice, Smyth, Mavor and Platow's (2017) study on the social influences on learning behaviour, Previte and Rusell-Bennett's (2015) study on the social influences 
on drinking behaviour and also Cruwys, Bevelander and Hermans's (2015) study on the social influences on food choice.

Even in the context of ecological behaviour, social influences are important drivers of these behaviours. Johnstone and Hooper (2016) reveal that social factors influence decisions to consume green products. Gifford and Nilsson (2014) find that the relationship between social influences and environmental concern and behaviour is significant. In Khorasanizadeh, Honarpour, Park, Parkkinen and Parthiban's (2016) study, the facilitating condition is found to have a positive impact towards the consumer's purchase decision.

In the UTAUT model, both social influence and facilitating conditions have been found to have direct effects on behaviour (Venkatesh et al. 2003). These relationships between situational factors and behaviour are well documented (Chen \& Li, 2010; Yu, 2014). Additionally, the UTAUT model has been applied in many different study contexts. But in a proenvironmental action study, limited research has adopted the social or environmental factors in explaining this issue. Hence, considering this gap, the following hypotheses are proposed:

H1: Social influences positively affect ecological behaviour.

$\mathrm{H} 2$ : Facilitating conditions positively affect ecological behaviour.

Behaviour is a function of the expectancies one has, and the value of the goal towards which one is working (Fishbein \& Ajzen, 1974). A person will act accordingly, if they think that such an act is important and has value to them. Hence, the degree of positive and negative values for a particular situation will be evaluated and it will affect the actual behaviour (Palmgreen, 1984). This theory helps to link the value-behaviour relationship. For instance, if a person thinks that protecting the environment is important and is for the benefit of future generations, then they tend to practice more proenvironment behaviour.

Ecoaltruistic values refer to those environmental attitudes regarded as feelings of moral obligation to behave in a way to benefit other human beings (Lopez \& Arango, 2008, p. 624). Basically, those who have a high level of environmental concern are those who believe the ecological environment and its conditions will affect different valued aspects, to others and to nature (Schultz, 2000). Specifically, openness to change is linked 
with the engagement of ecologically responsible behaviour (Geiger, Otto \& Schrader, 2017). Whereas in Zhang, Liu and Zhao's (2018) study, the openness to change value is found to have a direct impact on the citizens' environmental complaint intention. Their result outcome was based on the analysis and comparison between 29 cities in China.

In conclusion, personal values play an important role in explaining ecological actions. It has been empirically validated that personal values are linked to human behaviour based on the above discussion. In environmentalrelated research, personal values are therefore commonly used as the antecedent of ecological behaviour (Stern, 2000; Stern \& Dietz, 1994). Hence, the following hypotheses are proposed:

H3: Ecoaltruistic values positively affect ecological behaviour.

H4: Openness to change positively affect ecological behaviour.

Under the CBT, situational factors will influence human's belief, in turn affecting human behaviour (Beck, 1979). In other words, a belief that holds by a person (self-concept) is subject to external influences in the environment (Beck, 1979). For instance, if a person thinks that the online banking system is complex and insecure, he or she might refuse to use such technology. But if that person is being encouraged and trained by others in undertaking online banking transactions, this will facilitate the adoption of this new technology. This theory helps to link situational factors with human's beliefs. This relationship was tested mainly in the area of technology adoption and acceptance. However, there is a dearth of research that examines this relationship in the context of ecological behaviour. For instance, Lee (2010) did a study to explain the students' intention to continue using e-learning technology. He found that a supportive environment is noted as one of the factors that influenced the users' decisions.

As mentioned earlier, environmental factors are very limited in terms of their inclusion in pro-environmental studies. Hence, it is difficult to get similar and relevant literature for reference and the above discussion is mainly based on the context of technology acceptance. Specific to ecological behaviour, Mishra et al., (2017) find that there is a relationship between the environmental factors and the development of a positive belief towards green products in India. With such a positive belief, consumers are willing to pay more for the green products as compared to the conventional type of 
products. Another study conducted by Chan, Hon, Okumus and Chan (2014) in Hong Kong indicate that environmental factors significantly influence environmental beliefs among 385 hotel employees. In Mills,'s (2017) study on 60 farmers from the United Kingdom (UK), environmental factors such as financial incentives and regulatory approaches are found to be changing the farmers' willingness to adopt environmentally-positive behaviour.

There are many studies which have proven that external environmental or situational factors are influencing a person's perception and subsequently their actual behaviour (Beck, 1979; Venkatesh et al., 2003). However, in pro-environmental action research, researchers are only focused on internal (individual) factors in studying the ecological behaviour, such as attitudes, personalities, knowledge and intentions (Fraj \& Martinez, 2007; Wu et al., 2013). Few studies focus on external factors. UTAUT is a theory that incorporates both internal and external factors in studying technology acceptance and adoption issues. Since the present study is looking into the issue of energy-efficient appliance purchases, this model is appropriate to be applied and extended here as well. Hence, the following hypotheses are proposed:

H5: Social influences positively affect ecological beliefs.

H6: Facilitating conditions positively affect ecological beliefs.

Stern's (2000) VBN theory suggests that a strong ecological value orientation could influence the ecological beliefs and determine the practice of pro-environmental actions. Torelli and Kaikati (2009) reveal that human values direct the beliefs and behaviour of people and can be related to specific focuses of how people feel about themselves, their organisations and their decision making, as well as form interrelated structures among these components. Therefore, this theory helps to explain the relationship between ecological values and ecological beliefs (Jahangiri \& Zarei, 2016; LopezMosquera \& Sanchez, 2012). In brief, personal ecological values can be thought as a cognitive process or a way of thinking related to environmental beliefs, which act to increase the welfare of other social beings (Steg, Bolderdijk, Keizer \& Perlaviciute, 2014).

For example, Lopez-Mosquera and Sanchez (2012) state that ecological values influence general environmental beliefs. Their study analyses 194 visitors to a suburban Spanish park on their willingness to pay for park 
conservation. It is evident that those who have a high level of ecological values are more willing to pay for park conservation. Jahangiri and Zarei (2016) conducted a study to investigate the relationship between value orientation and attitudes toward the environment among 400 Shiraz University students. They find that there is a significant relationship between the amount of value orientation and attitude towards the environment, meaning that students with better value orientation scores are exhibiting a friendlier attitude towards the environment.

Numerous studies of pro-environmental attitudes have already shown that ecological value construction explains variance (Kaltenborn \& Bjerke, 2002) and behaviours (Siegrist, 1996). In Harju-Autti and Kokkinen's (2014) study comparing the cross-national environmental awareness, ecoaltruistic values are found to be correlated with environmental awareness.

In ecological behaviour research, it has been empirically validated that personal values are linked to some specific beliefs and behaviour (Stern, 2000; Stern \& Dietz, 1994). However, there is a dearth of research that has examined the direct relationship between ecological values and ecological beliefs. In the VBN theory (a prominent theory developed specifically for pro-environmental action study), the ecological beliefs variable is being represented by three different level of variables, such as the New Environmental (or Ecological) Paradigm (NEP), awareness of consequences (AC) and ascription of responsibility (AR). Therefore, considering this gap, the following hypotheses are proposed:

H7: Ecoaltruistic values positively affect ecological beliefs.

H8: Openness to change positively affect ecological beliefs.

Under the CBT, a person's core belief (self-concept) will influence behaviour (Beck, 1979). In other words, a belief that is held by a person (who you want to be) will be reflected in his or her behaviour (Beck, 1979). This theory helps to link the belief-behaviour relationship. There are many theories that found the relationships between attitude/belief and behaviour are correlated. For instance, in the Theory of Planned Behaviour (TPB) and Theory of Reasoned Action (TRA), it is accepted that the attitude towards the behaviour influences a person's behavioural intention and actual behaviour (Doane, Pearson \& Kelley, 2014). A study conducted by Mishra, Akman and Mishra (2014) that focused on the adoption of green information 
technology found that the positive attitude towards the green information technology (using TRA) is significantly influencing the usage intention and actual usage of such technology.

VBN theory, which was specifically developed for the study of ecological behaviour, is widely used in handling many environmental studies (Hiratsuka, Perlaviciute \& Steg, 2018; Poortvliet, Sanders, Weijma \& Vries, 2018). However, the belief component in this theory is not measured merely as the belief towards the given situation or phenomena. The three belief components in VBN are looking into the general world view of environmental concern and the awareness as well as the consequences of the behaviour. As such, the specific perceptions or beliefs on energy efficiency issues is not being measured.

There are behavioural theories which posit that a person's behaviour is influenced by their belief system. In general human behaviour research, TRA, TPB, CBT and VBN are the examples of theories that prove this beliefbehaviour relationship (Beck, 2008; Hagger et al., 2016; Knapp \& Beck, 1997; Paul, Modi \& Patel, 2016; Teo, 2016). In ecological behaviour research, even the ecological beliefs were not measured and tested directly toward ecological behaviour, it is still found that ecological beliefs have a relationship to various environmental actions or behaviours (Stern at al., 1995; Schultz \& Zelezny, 1999). Hence, the following hypothesis is proposed:

H9: Ecological beliefs positively affect ecological behaviour.

The CBT theory helps in explaining the mediating effect of ecological beliefs towards the relationship between values and behaviour. For instance, a person will find using a new software or application difficult if training support is not provided. But once that external support is given, it might change their perception of this new software or application once they get used to it. The mediating effect of belief components can be seen in VBN, the individual personal norms are influenced by the AC and the AR. If a person is aware of the negative consequences of his or her actions towards the environment and he or she could avert those consequences, the person will be likely to behave in a more ecological way in their daily life. There are results from previous studies that support this relationship, such as in Stern, Dietz and Kalof (1993) and Guagnano, Stern and Dietz (1995).

There are also other instances in which different mediating variables are 
included in the pro-environmental studies. In Paille and Mejia-Morelos's (2014) study, organisational support was included as the mediating variable in the relationship between personal values and ecological behaviour. The mediating effect of organisational support was found valid in this study. In another study conducted by Chua et al. (2016) pertaining to agrochemical purchases among Malaysian farmers, NEP is included as the mediating variable in the relationship between value orientations and personal norms. These studies are considered as the pioneers in studying the mediating effect in a pro-environmental context.

However, the mediating effect of ecological beliefs between situational factors and ecological behaviour is still neglected in academic research. As explained earlier, the easier and simpler form of ecological belief measurement was designed and included in the research model, its relationships with other study variables is to be reevaluated in this new ground. This is because with this new measurement approach, those tested relationships using old methods or approaches are no longer valid. Hence, the following hypotheses are proposed:

H10a: Ecological beliefs is mediating the relationship between social influences and ecological behaviour.

H10b: Ecological beliefs is mediating the relationship between facilitating conditions and ecological behaviour.

H11a: Ecological beliefs is mediating the relationship between ecoaltruistic values and ecological behaviour.

H11b: Ecological beliefs is mediating the relationship between openness to change and ecological behaviour.

Wegner and Wheatley (1999) explain that individuals usually experience "conscious will" when they interpret their own thoughts as the cause of their action. Conscious will can be viewed as a thought before the action (Wegner, 2002). This helps in explaining the appearance of situational variables to moderate the attitude-behaviour relation (Davidson \& Jaccard. 1979). Most human behaviour is volitional (the power of choosing or determining) in nature (Wegner \& Wheatley, 1999). This means that a human belief or attitude will not necessarily drive the actual behaviour. For instance, a lot of people realise that smoking is not good for health but still there are a lot of people smoking. Their smoking behaviour is obviously going through a 
cognitive thought and they opted to do so.

As mentioned earlier it is very rare for voluntariness to be included (either as antecedent or moderator variables) in pro-environmental studies. Hence, limited reference materials can be found but there are other instances in which different moderating variables are included in pro-environmental studies. This shows that the direct relationship between ecological beliefs and ecological behaviour is insufficient to explain the variance of ecological behaviour. Thus, a moderating variable is needed.

From the perspective of ecological behaviour, in Dagher, Itani and Kassar's (2015) study on 326 Lebanese consumers and also Suki's (2013) study on 200 Malaysian university students, gender was included as the mediating variable in the relationship between ecological beliefs and green purchasing behaviour. It was found that the mediating effect of gender is valid, thus suggesting that marketers need to recognise the uniqueness of both male and female markets. In Moon, Jeong and Choi's (2017) study on 1085 residents from South Korea, trust was found to be a valid moderator in the relationship between environmental attitude/concern and ecological behaviour.

Based on the above discussed rationale, the moderating effect of voluntariness in the technology acceptance context has already been examined. However, whether the moderating effect of voluntariness is also applicable in the context of Malaysian ecological behaviour is yet to be conclusive. Therefore, the following hypothesis is proposed:

H12: Voluntariness is moderating the relationship between ecological beliefs and ecological behaviour.

Thus, this study adopts the following research model that presents ecological behaviour as a consequence of direct and indirect relationships with ecological beliefs and both personal and environmental factors (see Figure 1).

\section{Methodology}

A questionnaire instrument has been designed to collect primary data for this study. Section A comprises 34 items to measure the individual's perception on all study variables. All measurement items are adapted from the literature 
Figure 1: Research Framework

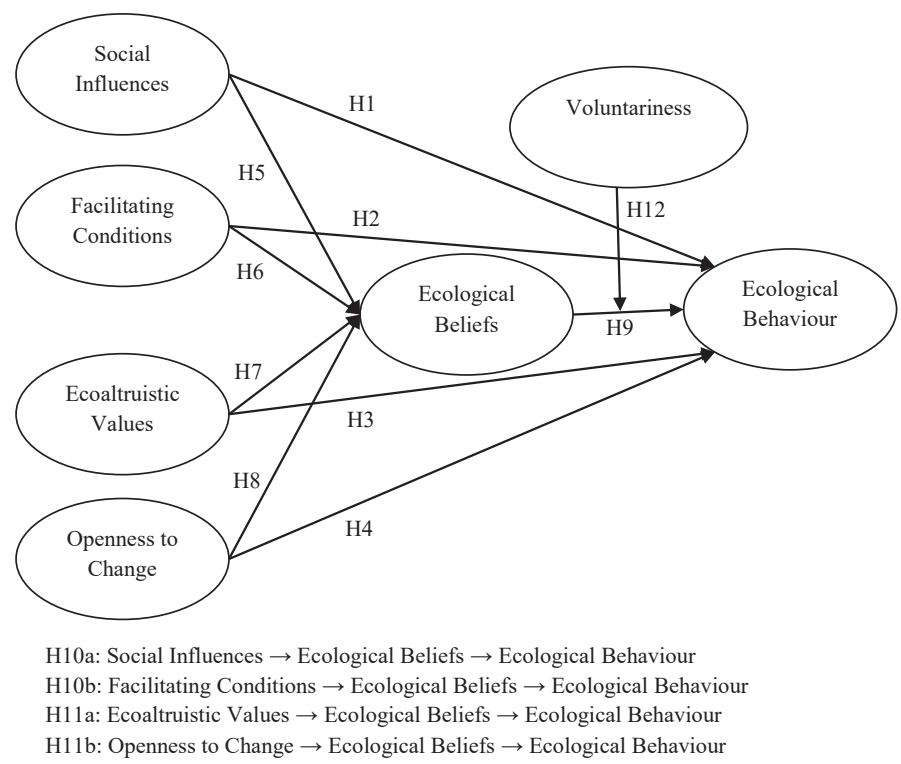

(see Appendix 1). Ecoaltruistic values are measured by using measurement items adapted from Kaiser et al. (1999). Openness to change is measured by using measurement items adapted from Susskind, Miller and Johnson (1998). Social influences, facilitating conditions and voluntariness are measured by using measurement items adapted from Venkatesh et al. (2003). Ecological beliefs are measured by using measurement items adapted from Singh (2011). Ecological behaviour is measured by using measurement items adapted from Fraj and Martinez (2007). A five-point Likert scale ranging from 1 = "strongly disagree" to 5 = "strongly agree" is used to each item. Section B comprises demographic questions that help to describe the characteristics of the respondents.

Non-probability sampling, specifically judgmental sampling, was employed in gathering the data for the present study. This is to ensure that the right respondents are targeted (Mohammad, Habib \& Alias, 2010). Respondents are required to have at least an actual purchase experience of household appliances within the last six months. At the beginning of the questionnaire, there is a filtering question to check on the recent purchase experience. This is meant to help respondents avoid answering a questionnaire that does not pertain to them. A total of 700 sets of 
questionnaires were distributed and 636 were returned. Since 44 sets had to be dropped, only 592 questionnaires were used for data analysis and this yielded an $84.6 \%$ of response rate. Most of the respondents are male $(62.9 \%)$, of Malay ethnicity (50.5\%), single (63.2\%) and from the age group of 21 years to 30 years $(63.2 \%)$.

\section{Data Analysis and Findings}

Prior to assessing the model, a multicollinearity test was carried out in order to check the similarity between the independent variables. Multicollinearity is a situation where there are two or more independent variables highly intercorrelated or inter-associated (Hair, Celsi, Money, Samouel \& Page, 2016). Collinearity analysis is automatically executed when running the partial least square (PLS) algorithm, where there were variance inflation factor (VIF) values generated. According to Hair, Mathews, Mathews and Sarstedt (2017), VIF values should not be greater than the 3.3 threshold. Any value greater than 3.3 means the presence of multicollinearity in the model (Kock, 2015). To get the VIF values, all the study variables in the model were tested for its direct relationships towards a single dependent variable. All VIF values were less than 3.3, and thus we can conclude that there is no multicollinearity issue in this research model.

Additionally, the presence of common method variance (CMV) was checked. SPSS factor analysis was used to check the CMV issue for this study. As recommended by Podsakoff, MacKenzie, Lee and Podsakaff (2003), Harman's single factor can be used to check the presence of CMV, in which all items (measuring latent variables) are loaded into one common factor. CMV exists when one factor explained more than $50 \%$ of the variance. The results showed that none of the factors explained more than $50 \%$ of the variance, hence the CMV was not considered a serious problem in this study.

To assess the model, this study used SmartPLS 3.0 (Ringle, Wende $\&$ Will, 2015) to estimate the parameters in the measurement model and structural model. The measurement model, which represents the relationship between a construct and its relevant indicators, was estimated in term of its validity and reliability. The assessment of the structural model is aimed to evaluate the causal relationships among the constructs in a hypothetical model. PLS algorithm followed by bootstrapping procedures with 5,000 resamples were executed. 
Factor loading, composite reliability and Cronbach's alpha values were generated for assessing reliability. The suggested standard for factor loading must be greater 0.60 (Chin, 1998), composite reliability must be greater than 0.70 (Henseler, Christain, Ringle \& Sinkovies, 2009) and Cronbach's alpha must be greater than 0.70 (Pallant, 2013). Table 1 shows the results of the measurement model. There were a few items that were dropped due to their cut-off points falling below the suggested standards. Eight items were dropped for further analysis in order to meet the minimum criteria for reliability and validity. Two items (OTC2R, OTC3R) from openness to change construct, one item (EF6R) from ecological beliefs construct and five items (EB1R, EB6, EB7R, EB8R, EB9) from ecological behaviour construct were dropped. As such, the reliability of the measurement model reached a satisfactory level.

Table 1: Evaluation of Measurement Model

\begin{tabular}{|c|c|c|c|c|c|}
\hline Construct & Item & Loadings & Composite & AVE & Cronbach \\
\hline Ecoaltruistic Values & $\begin{array}{l}\text { EAV1 } \\
\text { EAV2 } \\
\text { EAV3 } \\
\text { EAV4 }\end{array}$ & $\begin{array}{l}0.744 \\
0.866 \\
0.871 \\
0.662\end{array}$ & 0.868 & 0.625 & 0.797 \\
\hline Ecological Behaviour & $\begin{array}{l}\text { EB2 } \\
\text { EB3 } \\
\text { EB4 } \\
\text { EB6 }\end{array}$ & $\begin{array}{l}0.638 \\
0.770 \\
0.729 \\
0.663\end{array}$ & 0.794 & 0.527 & 0.657 \\
\hline Ecological Beliefs & $\begin{array}{l}\text { EF1 } \\
\text { EF2 } \\
\text { EF3 } \\
\text { EF4 } \\
\text { EF5 }\end{array}$ & $\begin{array}{l}0.729 \\
0.733 \\
0.759 \\
0.746 \\
0.619\end{array}$ & 0.842 & 0.517 & 0.765 \\
\hline Facilitating Conditions & $\begin{array}{l}\mathrm{FC} 1 \\
\mathrm{FC} 2 \\
\mathrm{FC} 3 \\
\mathrm{FC} 4\end{array}$ & $\begin{array}{l}0.704 \\
0.802 \\
0.791 \\
0.760\end{array}$ & 0.850 & 0.586 & 0.764 \\
\hline Openness to Change & $\begin{array}{l}\text { OTC1 } \\
\text { OTC4 } \\
\text { OTC5 } \\
\text { OTC6 }\end{array}$ & $\begin{array}{l}0.698 \\
0.754 \\
0.736 \\
0.772\end{array}$ & 0.829 & 0.548 & 0.727 \\
\hline
\end{tabular}




\begin{tabular}{lccccc}
\hline \multicolumn{1}{c}{ Construct } & Item & Loadings & Composite & AVE & Cronbach \\
\hline Social Influences & SI1 & 0.851 & 0.906 & 0.762 & 0.844 \\
& SI2 & 0.880 & & & \\
& SI3 & 0.888 & & & \\
Voluntariness & VL1 & 0.716 & 0.841 & 0.639 & 0.732 \\
& VL2 & 0.809 & & & \\
& VL3 & 0.865 & & & \\
\hline
\end{tabular}

Discriminant validity is assessed by using two methods: FornellLarcker's (1981) criterion and Henseler, Ringle and Sarstedt's (2015) Heterotrait-Monotrait (HTMT) methods. In Fornell-Larcker's (1981) criterion method, the square root of the AVE of a construct has to be greater than the correlations between other constructs in row and columns. Table 2 shows that this condition is met, and thereby confirming the discriminant validity at construct level. In HTMT method, convergent validity is established if HTMT values are less than 0.09 for constructs that are conceptually similar, and less than 0.85 for constructs that are conceptually different (Henseler et al., 2015). All HTMT values generated in this study are less than the cut-off point of 0.85 , thus establishing discriminant validity.

Table 2: Discriminant Validity, Fornell-Larcker Method

\begin{tabular}{lccccccc}
\hline & EAV & EB & EF & FC & OTC & SI & VL \\
\hline EAV & $\mathbf{0 . 7 9 1}$ & & & & & & \\
EB & 0.146 & $\mathbf{0 . 7 0 2}$ & & & & & \\
EF & 0.434 & 0.284 & $\mathbf{0 . 7 1 9}$ & & & & \\
FC & 0.328 & 0.289 & 0.383 & $\mathbf{0 . 7 6 5}$ & & & \\
OTC & 0.428 & 0.309 & 0.482 & 0.478 & $\mathbf{0 . 7 4 0}$ & & \\
SI & 0.203 & 0.298 & 0.357 & 0.408 & 0.414 & $\mathbf{0 . 8 7 3}$ & \\
VL & 0.163 & 0.287 & 0.248 & 0.367 & 0.271 & 0.361 & $\mathbf{0 . 7 9 9}$ \\
\hline
\end{tabular}

In order to assess the structural model (see Figure 2), the significance of path coefficient, coefficient of determination $\left(\mathrm{R}^{2}\right)$, effect size $\left(\mathrm{F}^{2}\right)$ and predictive relevance $\left(\mathrm{Q}^{2}\right)$ values were generated (Hair, Hult, Ringle and Sarstedt, 2014). As shown in Table 3, SI $(\mathrm{B}=0.150, \mathrm{P}<0.01)$, FC (B $=0.124, \mathrm{P}<0.01)$ and OTC $(0.145, \mathrm{P}<0.01)$ were positively related to ecological behaviour, thus $\mathrm{H} 1, \mathrm{H} 2$ and $\mathrm{H} 4$ were supported. This result is aligned with the previous theories (Stern, 2000; Venkatesh et al., 2003), 
where personal characteristics and environmental factors influence human behaviour. However, for $\mathrm{H} 3$, that testing of the relationship between ecoaltruistic values and ecological behaviour is found to be not supported. Such research results could be due to the dropping of antecedent variable of personal norm in VBN theory.

Figure 2: PLS Path Model

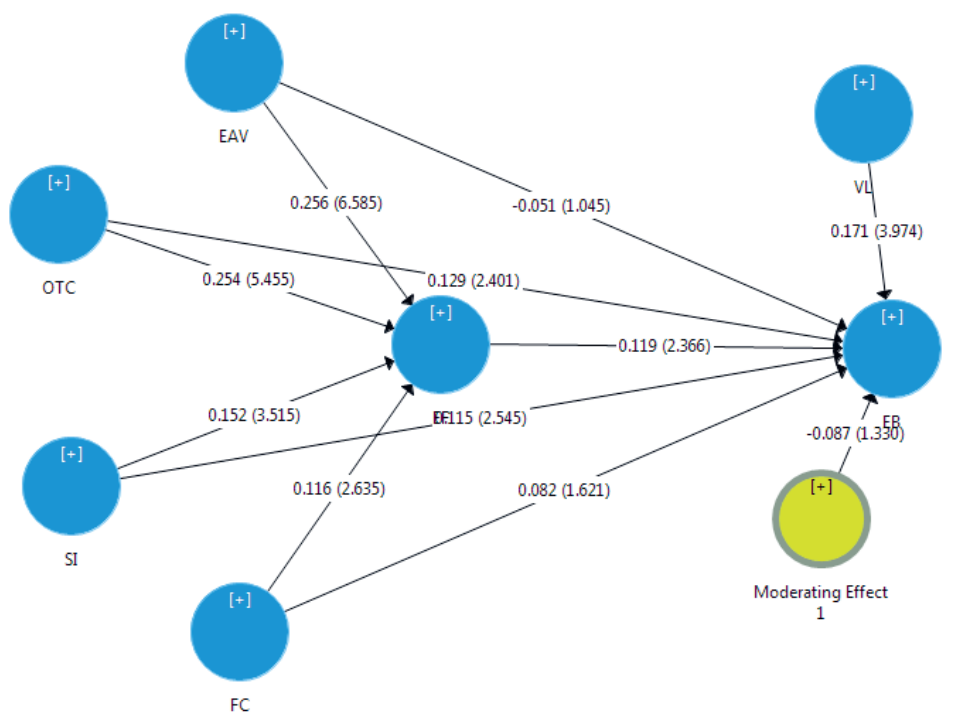

From Table 3, SI $(\mathrm{B}=0.152, \mathrm{P}<0.01), \mathrm{FC}(\mathrm{B}=0.116, \mathrm{P}<0.01)$, EVA $(\mathrm{B}=0.256, \mathrm{P}<0.01)$ and OTC $(\mathrm{B}=0.254, \mathrm{P}<0.01)$ are found to be positively related to ecological beliefs, thus $\mathrm{H} 5, \mathrm{H} 6, \mathrm{H} 7$ and $\mathrm{H} 8$ are supported as well. These research results are aligned with many behavioural theories developed in measuring both general behaviour and ecological behaviour (Chan et al., 2018). For the relationship between ecological beliefs and ecological behaviour, EF $(0.131, \mathrm{P}<0.01)$ was positively related to $\mathrm{EB}$, which provided support for H9. It shows that this direct beliefbehaviour relationship is valid. Hence, the belief components in VBN can be measured by using a single variable instead of represented through three different variables. With that, it was proved that a more simple and pure ecological belief variable can be used to ease the measurement of this beliefbehaviour relationship. It is concluded that eight out of nine direct effects are supported, while H6, which tests the direct relationship between ecoaltruistic values and ecological behaviour, is not supported. 
Table 3: Evaluation of Structural Model

\begin{tabular}{ccccccc}
\hline Hypothesis & Path & Coefficient & SD & t-value & F $^{\mathbf{2}}$ & Supported \\
\hline H1 & $\mathrm{SI} \rightarrow \mathrm{EB}$ & 0.150 & 0.045 & 3.306 & 0.020 & Yes \\
H2 & $\mathrm{FC} \rightarrow \mathrm{EB}$ & 0.124 & 0.051 & 2.452 & 0.013 & Yes \\
H3 & $\mathrm{EAV} \rightarrow \mathrm{EB}$ & 0.042 & 0.051 & 0.828 & 0.002 & No \\
H4 & $\mathrm{OTC} \rightarrow \mathrm{EB}$ & 0.145 & 0.055 & 2.628 & 0.015 & Yes \\
H5 & $\mathrm{SI} \rightarrow \mathrm{EF}$ & 0.152 & 0.043 & 3.519 & 0.027 & Yes \\
H6 & $\mathrm{FC} \rightarrow \mathrm{EF}$ & 0.116 & 0.043 & 2.694 & 0.014 & Yes \\
H7 & $\mathrm{EAV} \rightarrow \mathrm{EF}$ & 0.256 & 0.038 & 6.724 & 0.078 & Yes \\
H8 & $\mathrm{OTC} \rightarrow \mathrm{EF}$ & 0.254 & 0.046 & 5.543 & 0.062 & Yes \\
$\mathrm{H} 9$ & $\mathrm{EF} \rightarrow \mathrm{EB}$ & 0.131 & 0.050 & 2.633 & 0.014 & Yes \\
\hline
\end{tabular}

Next, this study examined the presence of mediation effect by using a bootstrapping procedure as suggested by Preacher and Hayes (2008). The results in Table 4 show that the indirect effect of $\beta 1=0.020$ (95\% CI: 0.004 , 0.042 ) and significant with a t-value of 2.058 , the indirect effect of $\beta 3=$ $0.034(95 \% \mathrm{CI}: 0.008,0.063)$ and significant with a t-value of 2.364 , and the indirect effect of $\beta 4=0.033$ (95\% CI: $0.008,0.062)$ and significant with a t-value of 2.440. These results provide support for H10a, H11a and H11b respectively.

Table 4: Hypotheses Testing for Indirect Effects

\begin{tabular}{|c|c|c|c|c|c|c|}
\hline Hypothesis & Path & $\begin{array}{l}\text { Indirect } \\
\text { Effect }\end{array}$ & $\begin{array}{c}95 \% \\
\text { CI }\end{array}$ & SD & t-value & Supported \\
\hline $\mathrm{H} 10 \mathrm{a}$ & $\beta 1: \mathrm{SI} \rightarrow \mathrm{EF} \rightarrow \mathrm{EB}$ & 0.020 & $\begin{array}{c}0.004- \\
0.042\end{array}$ & 0.010 & 2.058 & Yes \\
\hline $\mathrm{H} 10 \mathrm{~b}$ & $\beta 2: \mathrm{FC} \rightarrow \mathrm{EF} \rightarrow \mathrm{EB}$ & 0.015 & $\begin{array}{c}0.002- \\
0.034\end{array}$ & 0.008 & 1.845 & No \\
\hline H11a & $\beta 3: \mathrm{EAV} \rightarrow \mathrm{EF} \rightarrow \mathrm{EB}$ & 0.034 & $\begin{array}{c}0.008- \\
0.063\end{array}$ & 0.014 & 2.364 & Yes \\
\hline $\mathrm{H} 11 \mathrm{~b}$ & $\beta 4: \mathrm{OTC} \rightarrow \mathrm{EF} \rightarrow \mathrm{EB}$ & 0.033 & $\begin{array}{c}0.008- \\
0.062\end{array}$ & 0.014 & 2.440 & Yes \\
\hline
\end{tabular}

Note: CI - confidence interval.

Thus, it is concluded that three out of four mediating effects are supported. The ecological beliefs mediate the relationship between social 
influences and ecological behaviour, the relationship between ecoaltruistic values and ecological behaviour and the relationship between openness to change and ecological behaviour. But, the mediating effect of ecological beliefs in the relationship between facilitating conditions and ecological behaviour is not supported. Such a research result is compatible with the UTAUT, where the facilitating factors only make an act easy to carry out (Venkatesh et al., 2003). For instance, a consumer may have bought the energy-efficient appliance due to the product discount or a promotion drive, instead of taking into account the environmental issue. The results are consistent with the VBN theory that was developed specifically to measure the environmental behaviour (Stern, 2000).

To consider a moderating relationship to be significant, a minimum t-value must be greater than 1.96 (Hair et al., 2014). The bootstrapping analysis shows that the moderating effect of $\mathrm{H} 12$ is not significant with $\beta=$ $-0.087, \mathrm{t}=1.330, \mathrm{p}>0.05$. Table 5 depicts the bootstrapping information about this moderating effect. The moderating role of voluntariness is not supported at $\mathrm{p}>0.05$, implying that voluntariness is not moderating the relationship between ecological beliefs and ecological behaviour. The Malaysian government is aggressively promoting these energy-efficient appliances. There could then be a misunderstanding by consumers that the government is forcing them to use these types of appliances. As such, the consumers feel that they have no freedom in making their own decision.

Table 5: Hypothesis Testing for Moderating Effect

\begin{tabular}{ccccccc}
\hline Hypothesis & Path & $\begin{array}{c}\text { Moderating } \\
\text { Effect }\end{array}$ & $\begin{array}{c}\mathbf{9 5 \%} \\
\text { CI }\end{array}$ & SD & t-value & Supported \\
\hline \multirow{2}{*}{$\mathrm{H} 12$} & $\mathrm{EF} \rightarrow \mathrm{VL} \rightarrow \mathrm{EB}$ & -0.087 & $\begin{array}{c}0.204- \\
0.123\end{array}$ & 0.066 & 1.330 & No \\
\hline
\end{tabular}

Note: CI - confidence interval.

To assess the overall model, the $\mathrm{R}^{2}$ and $\mathrm{Q}^{2}$ values for the endogenous variables are obtained via PLS algorithm and blindfolding procedures. Table 6 depicts the $\mathrm{R}^{2}$ and $\mathrm{Q}^{2}$ values for ecological beliefs and ecological behaviour. is The $\mathrm{R}^{2}$ of 0.333 indicates that both personal values and environmental factors explained $33.3 \%$ of the variance in ecological beliefs. The $\mathrm{R}^{2}$ of 0.157 implies that ecological beliefs explained $15.7 \%$ of the 
variance in the ecological behaviour. $\mathrm{Q}^{2}$ values of 0.158 for ecological beliefs and 0.073 for ecological behaviour were obtained after the blindfolding procedure. $\mathrm{A} \mathrm{Q}^{2}$ value larger than zero indicates the predictive relevance of the path model (Henseler et al., 2009). Both $\mathrm{Q}^{2}$ values generated in Table 6 are greater than zero, therefore, the PLS path model for the present study is accepted and supported in terms of its relevancy in studying this phenomenon. Thus, it is concluded that the exogenous variables show their capability to predict the endogenous variables.

Table 6: $\mathrm{R}^{2}$ and $\mathrm{Q}^{2}$ Values

\begin{tabular}{cccc}
\hline Predictor Construct & Target Construct & $\mathbf{R}^{\mathbf{2}}$ & $\mathbf{Q}^{\mathbf{2}}$ \\
\hline EAV, OTC, SI, FC and EF & EB & 0.157 & 0.073 \\
EAV, OTC, SI, FC & EF & 0.333 & 0.158 \\
\hline
\end{tabular}

\section{Conclusion}

This study examines the relationship between the value-belief basis and proenvironmental behaviour in energy efficient appliances. More specifically, it examines whether values, beliefs and general environmental factors are related to ecological behaviour. For that purpose, appropriate mediators and moderators are included to reflect current realities.

The results show that social influences, facilitating conditions and openness to change significantly and positively affect ecological behaviour. However, the relationship between ecoaltruistic values and ecological behaviour is not supported in this study. Additionally, social influences, facilitating conditions, ecoaltruistic values and openness to change are found to significantly and positively affect ecological beliefs. Ecological beliefs are also found to significantly and positively affect ecological behaviour. For mediating effects, ecological beliefs mediate the relationship between social influences and ecological behaviour, the relationship between ecoaltruistic values and ecological behaviour and the relationship between openness to change and ecological behaviour. Contrary to this, ecological beliefs do not mediate the relationship between facilitating conditions and ecological behaviour. For moderating effect, voluntariness does not moderate the relationship between ecological beliefs and ecological behaviour.

Hence, external influences can be used to facilitate the adoption of energy-efficient appliances (Venkatash et al., 2003). Incentive programmes 
for consumer referrals should be in place to encourage more adoption and usage. This strategy is very common in technology-related product markets. A win-win situation is created, whereby consumers who successfully recommend new purchases will be rewarded for their effort. Incentive programmes directed to consumers can reduce their perceived risks in purchasing new products (Venkatash et al., 2003).

\section{Theoretical and Practical Contribution}

\subsection{Theoretical contribution}

The theoretical contribution of this study involves integrating different theories to form a more robust framework in dealing with pro-environmental action-related issues and studies. This study used VBN theory as the basic foundation for the conceptual framework. Due to its weaknesses, additional theories were adopted and integrated to form a more comprehensive framework. For instance, SCT is included to form the basis for a justification of human behaviour, influenced by both personal and external, particularly environmental, factors. UTAUT environmental factors, such as social influences, facilitating conditions and voluntariness, are included in the conceptual framework for this study.

The findings from this study provide an understanding of the internal and external factors that influence the commitment of individual consumers in purchasing energy-efficient appliances. Previous studies attempted to discover the practice of ecological behaviour that focus on internal factors, such as attitudes, personalities and knowledge (Fraj \& Martinez, 2006). As such, this study attempts to include some external factors to study this issue from both internal and external perspectives. The insights from this study found that both social influences and facilitating conditions exert influence on ecological beliefs towards energy conservation and ecological behaviour in purchasing energy-efficient appliances.

This study's insights underline the importance of ecological beliefs as mediating the relationships between ecoaltruistic values-ecological behaviour, openness to change-ecological behaviour and social influencesecological behaviour. More educational programmes and messages must be channeled to consumers (including the general public) that shape the general beliefs in the importance of conserving electricity. Belief is a strong driver of 
ecological behaviour (Chua et al., 2016). With such beliefs taking hold, more consumers will be committed and obligated to purchase energy efficient appliances for the betterment of the environment. Another contribution of this study is the inclusion of the moderator in the research model. The new direct relationships between value-belief-behaviour have been observed, including the moderating effect of voluntariness on the relationship between ecological beliefs and ecological behaviour. The findings, however, did not support the moderating effect of voluntariness.

The study of ecological behaviour is very limited in Malaysia compared to in other countries such as Spain, the United States (US), Switzerland, Romania, Turkey and Nepal. Thus, this study involving Malaysia contributes positively to the body of knowledge, namely to the role of both personal and situational factors and ecological beliefs in driving ecological behaviour. Factors contributing to influence behaviour are likely to vary with target users and context. By applying different theories, it serves as a validation process for these theories in different contexts and geographical locations.

\subsection{Managerial contribution}

For the Malaysian government, this study provides a big picture of the relevant aspects pertaining to ecological behaviour related to the purchase of energy-efficient appliances. The labeling programme for energy-efficient appliances was started in 2005 by the government. A lot of resources have been invested into the implementation of various educational programmes, with incentives given to both manufacturers and individual consumers. However, there has been no follow up study by the government to measure its success.

The instrument for this study was designed to capture some useful information in explaining consumer profiles and behavioural patterns related to energy efficient appliances. This information provides some insights as to the frequent purchasers of energy-efficient appliances. Their characteristics have been demographically compiled and the overall consumer profile defined in Malaysia. Additionally, the purchase reasons or motivations are also recorded, thereby providing information for planning purposes by both government agencies and non-governmental organisations (NGOs) when dealing with the environment issue. It helps in identifying and segmenting household appliance purchaser groups for the formulation of more targeted 
education and promotional programmes.

For environmental agencies, they can make use of the findings to encourage consumers to be responsible towards the environment, especially in their daily purchases. Various educational or training programmes can be used to encourage and to educate more environmentally friendly consumption patterns. Such training can also teach consumers how to differentiate green and non-green products that will help in protecting the environment.

For industry and marketing practitioners, this study provides information necessary in explaining what promotes and hinders ecological behaviour. For instance, information on individual differences and purchase reasons will help marketers to segment their market and to formulate various strategies to cater to various consumer groups. Their purchase motivations need to be identified to promote acceptance and effective purchases. With good segmentation, different marketing strategies can be implemented for various groups in line with the objectives.

For marketers, appropriate promotions can be planned by using the recorded sales data. With good promotion strategies, industries can minimise their losses due to unsold stocks. Different incentives or bundle promotions can help to boost the sales on the not-so-popular items so that cash can be generated. Since the environmental factors are found to influence purchase decisions, marketers can include some of these factors, such as incentives for recommendation from other consumers, training and education programmes, for example in promoting energy-efficient appliances.

The outcome of this study enables companies to formulate appropriate strategies to tap into the market. Companies will be aware of the facilitating factors from the environment that may help to promote the purchase and usage of energy efficient appliances. For instance, industries can provide more educational and after-sales service programmes to reduce some of the risks that consumers may face when using such appliances.

\section{Limitations and Future Research Directions}

The present study confirmed the direct and indirect influences of both personal and environmental factors and ecological beliefs towards ecological behaviour of energy-efficient appliance purchases. No matter how good your research design is, there will still be imperfections in a research 
paper. Research limitations highlighted here can be used as guidelines for improving future research.

First, the present study uses a cross-sectional survey design and not a longitudinal survey design. A longitudinal survey design would be more appropriate when studying the perceptions of the respondents. Second, ecological beliefs as a concept is still considered a relatively new construct in this field of study. Hence, limited literature is available to generate quality questionnaire items for measuring this construct. Third, there are situational variables that have not been included in the present study. There are many influencing factors on a phenomenon. The present study is only focused on the situational variables being studied and transferred from UTAUT, due to the similarity of the study with technology acceptance.

These suggestions and recommendations are discussed as to serve as guidelines for future research. Future research could compare the results between different groups/segments among respondents. Cross-cultural comparison can also be a future research direction, especially in Malaysia with its different races or comparison across different countries. This can be used to test the generalisation power of the model across different groups. Additionally, the different environmental factors may have a different impact on behaviour. In reality, there are more situational factors that impact on human behaviour. Such factors need to be identified and tested in terms of their relationship with ecological beliefs and ecological behaviour. For instance, infrastructure, economic and geographical factors could be investigated. The four items used to measure ecological beliefs are considered too simple. This is to suggest that future research can focus in developing and expanding more items in measuring this concept. More dimensions can be added to cover this concept more comprehensively. This model can also be applied to different studies so as to validate its results in different settings.

\section{References}

Axelrod, L.J., \& Lehman, D.R.Z. (1993). Responding to environmental concern: What factors guide individual action? Journal of Environmental Psychology, 13, 149-159. doi: 10.1016/S0272-4944(05)80147-1

Bandura, A. (1997). Self-Efficacy: The Exercise of Control. New York: W.H. Freeman. 
Beck, A.T. (2008). The evolution of the cognitive model of depression and its neurobiological correlates. American Journal of Psychiatry, 165, 969977. doi: 10.1176/appi.ajp.2008.08050721

Beck, A.T. (1979). Cognitive Therapy and the Emotional Disorders. New York: International University Press.

Bues, M., Steiner, M., Stafflage, M., \& Manfred, L. (2017). How mobile in-store advertising influences purchase intention: Value drivers and mediating effects from a consumer perspective. Psychology and Marketing, 34(2), 157-174. doi.org/10.1002/mar.20981

Chan, S.K., Quoquab, F., \& Basiruddin, R. (2018). The mediating role of ecological beliefs between personal values and ecological behaviour. The Turkish Online Journal of Design, Art and Communication, September 2018, Special Edition, 1322-1329. doi: 10.7456/1080SSE/177

Chan, E.S.W., Hon, A.H.Y., Okumus, F., \& Chan, W. (2014). An empirical study of environmental practices and employee ecological behaviour in the hotel industry. Journal of Hospitality and Tourism Research, 41(5), 585-608. doi: 10.1177/1096348014550873

Chen, S.C., \& Li, S.H. (2010). Consumer adoption of e-service: Integrating technology readiness with the theory of planned behaviour. African Journal of Business Management, 4(16), 3556-3563. Retrieved from https://academicjournals.org/article/article1380705096.pdf

Cherry, C., Hopfe, C., MacGillivray, B., \& Pidgeon, N. (2017). Homes as machines: Exploring expert and public imaginaries of low carbon housing futures in the United Kingdom. Energy Research and Social Science, 23, 36-45. doi.org/10.1016/j.erss.2016.10.011

Chin, W.W. (1998). Issues and opinions on structural equation modeling. MIS Quarterly, 22(1), 7-26. Retrieved from https://www.jstor.org/ stable/249647

Choi, H, Kim, S.H., \& Lee, J. (2010). Role of network structure and network effects in diffusion of innovations. Industrial Marketing Management, 39(1), 170-177. doi: 10.1016/j.indmarman.2008.08.006

Chou, C.J. (2014). Hotels' environmental policies and employee personal environmental beliefs: Interactions and outcomes. Tourism Management, 40, 436-446. doi.org/10.1016/j.tourman.2013.08.001

Chua, K.B., Quoquab, F., Mohammad, J., \& Basiruddin, R. (2016). The mediating role of new ecological paradigm between value orientations and pro-environmental personal norm in the agricultural context. 
Asia Pacific Journal of Marketing and Logistics, 28(2), 323-349. doi. org/10.1108/APJML-09-2015-0138

Cigno, K., \& Bourn, D. (1998). Cognitive-behavioural Social Work in Practice. London: Routledge.

Cruwys, T., Bevelander, K.E., \& Herman, R.C.J. (2015). Social modelling of eating: A review of when and why social influence affects food intake and choice. Appetite, 86, 3-18. doi.org/10.1016/j.appet.2014.08.035

Dagher, G.K., Itani, O., \& Kassar, A.N. (2015). The impact of environment concern and attitude on green purchasing behaviour: Gender as the moderator. Contemporary Management Research, 11(2), 179-206. doi. org/10.7903/cmr.13625

Davis, F.D. (1989). Perceived usefulness, perceived ease of use and user acceptance of information technology. MIS Quarterly, 13(3), 319-340. doi: $10.2307 / 249008$

Davidson, A.R., \& Jaccard, J.J. (1979). Variables that moderate the attitudebehaviour relation: Results of a longitudinal survey. Journal of Personality and Social Psychology, 37(8), 1364-1376. doi.org/10.1037/00223514.37.8.1364

Doane, A.N., Pearson, M.R., \& Kelley, M.L. (2014). Predictors of cyberbullying perpetration among college students: An application of the theory of reasoned action. Computers in Human Behaviour, 36, 154-162. doi.org/10.1016/j.chb.2014.03.051

Donovan, R.J., \& Rossiter, J.R. (1982). Store atmosphere: An environmental psychology approach. Journal of Retailing, 58, 34-57. Retrieved from https://www.researchgate.net

Fishbein, M., \& Ajzen, I. (1975). Belief, Attitude, Intention and Behaviour: An Introduction to Theory and Research. Reading, MA: Addison-Wesley.

Fornell, C., \& Larcker, D.F. (1981). Evaluating structural equation models with unobservable variables and measurement error. Journal of Marketing Research, 18(1), 39-50. doi: 10.2307/3151312

Fraj, E., \& Martinez, E. (2006). Influence of personality on ecological consumer behavior. Journal of Consumer Behaviour, 5, 167-181. doi. org/10.1002/cb.169

Fraj, E., \& Martinez, E. (2007). Ecological consumer behaviour: An empirical analysis. International Journal of Consumer Studies, 31, 2633. doi.org/10.1111/j.1470-6431.2006.00565.x

Gatersleben, B., Murtagh, N., \& Abrahamse, W. (2014). Values, identity and 
pro-environmental behavior. Contemporary Social Science, 9(4), 374392. doi.org/10.1080/21582041.2012.682086

Geiger, S.M., Otto, S., \& Schrader, U. (2017). Mindfully green and healthy: An indirect path from mindfulness to ecological behaviour. Frontiers in Psychology, 8. doi.org/10.3389/fpsyg.2017.02306

Gifford, R., \& Nilsson, A. (2014). Personal and social factors that influence pro-environmental concern and behaviour: A review. International Journal of Psychology, 49(3), doi.org/10.1002/ijop.12034

Gonzalez, E.M., Felix, R., Carrete, L., Centeno, E., \& Castano, R. (2015). Green shades: A segmentation approach based on ecological consumer behaviour in an emerging economy. Journal of Marketing Theory and Practice, 23(3), 287-302. doi.org/10.1080/10696679.2015.1032395

Guagnano, G.A., Stern, P.C., \& Dietz, T. (1995). Influences on attitudebehaviour relationships: a natural experiment with curbside recycling. Environment Behaviour, 27, 699-718. doi.org/10.1177/0013916595275005 Guckian, M., Young, R.D., \& Harbo, S. (2017). Beyond green consumerism: Uncovering the motivations of green citizenship. Michigan Journal of Sustainability, 5(1), 73-94. doi.org/10.3998/mjs.12333712.0005.105

Hagger, M.S., Chan, D.K.C., Protogerou, C., \& Chatzisarantis, N.L.D. (2016). Using meta-analytic path analysis to test theoretical predictions in health behaviour: An illustration based on meta-analyses of the theory of planned behaviour. Preventive Medicine, 89, 154-161. doi: 10.1016/j. ypmed.2016.05.020

Hair, J.F., Mathews, L.M., Mathews, R.L., \& Sarstedt, M. (2017). PLS-SEM or CB-SEM: Updated guidelines on which method to use. International Journal of Multivariate Data Analysis, 1(2), 107-123. doi: 10.1504/ IJMDA.2017.087624

Hair, J.F., Celsi, M., Money, A., Samouel, P., \& Page, M. (2016). The Essentials of Business Research Methods. $3^{\text {rd }}$ Edition. New York: Routledge.

Hair, J.F., Hult, G.T.M., Ringle, C.M., \& Sarstedt, M. (2014) A Primer on Partial Least Squares Structural Equation Modelling (PLS-SEM). United States: Sage Publication.

Harju-Autti, P., \& Kokkinen, E. (2014). A novel environmental awareness index measured cross-nationally for fifty seven countries. Universal Journal of Environmental Research and Technology, 4(4), 178-198. Retrieved from http://www.environmentaljournal.org/4-4/ujert-4-4-1.pdf 
Harman, J., \& Koivisto, J. (2015). Working out for likes: An empirical study on social influence in exercise gamification. Computers in Human Behaviour, 50, 333-347. doi: 10.1016/j.chb.2015.04.018

Henseler, J., Ringle, C.M., \& Sarstedt, M. (2015). A new criterion for assessing discriminant validity in variance based structural equation modeling. Journal of Academy of Marketing Science, 43(1), 115-135. doi: 10.1007/s11747-014-0403-8

Henseler, J., Christain, M., Ringle, R., \& Sinkovies, R.R. (2009). The use of partial least square path modelling in international marketing. Advances in International Marketing, 20(1), 277-319. doi.org/10.1108/S14747979(2009)0000020014

Hiratsuka, J., Perlaviciute, G., \& Steg, L. (2018). Testing VBN theory in Japan: Relationships between values, beliefs, norms and acceptability and expected effects of a car pricing policy. Transportation Research Part F: Traffic Psychology and Behaviour, 35, 74-83. doi: 10.1016/j. $\operatorname{trf} .2017 .12 .015$

Huang, H. (2016). Media use, environmental beliefs, self-efficacy and proenvironmental behavior. Journal of Business Research, 69(6), 22062212. doi: 10.1016/j.busres.2015.12.031

Ibrahim, E.B., \& Harrison, T. (2019). The impact of internal, external and competitor factors on marketing strategy performance. Journal of Strategic Marketing, May 2019. doi.org/10.1080/096525 4X.2019.1609571

Jahangiri, J., \& Zarei, A. (2016). The relationship between value orientation and attitudes toward the environment case study: Shiraz University students. International Journal of Humanities and Cultural Studies, 3(2), 850-861. Retrieved from https://www.ijhcs.com/index.php/ijhcs/article/ view/2776/2564

Johnstone, M.L., \& Hooper, S. (2016). Social influence and green consumption behaviour: A need for greater government involvement. Journal of Marketing Management, 32(9-10), 827-855. doi.org/10.1080 /0267257X.2016.1189955

Judge, T.A., Bono, J.E., Ilies, R., \& Gerhardt, M.W. (2002). Personality and leadership: A qualitative and quantitative review. Journal of Applied Psychology, 87(4), 765-780. doi.org/10.1037/0021-9010.87.4.765

Kaiser, F.G., Hubner, G., \& Bogner, F.X. (2005). Contrasting the theory of planned behaviour with the value-belief-norm model in explaining 
conservation behavior. Journal of Applied Social Psychology, 35, 21502170. doi.org/10.1111/j.1559-1816.2005.tb02212.x

Kaiser, F.G., Wolfing, S., \& Fuhrer, U. (1999). Environmental attitude and ecological behavior. Journal of Environmental Psychology, 19, 1-19. Retrieved from https://home.zhaw.ch/cahu/dateien/

Kaltenborn, B.P., \& Bjerke, T. (2002). Associations between environmental value orientations and landscape preferences. Landscape and Urban Planning, 59, 1-11. doi: 10.1016/S01692046(01)00243-2

Karpudewan, M., Ismail, Z., \& Roth, W.M. (2012). The efficacy of a green chemistry laboratory-based pedagogy: Changes in environmental values of Malaysia pre-service teachers. International Journal of Science and Mathematics Education, 10(3), 497-529. Retrieved from https://link. springer.com/article/10.1007/s10763-011-9295-y

Khan, I. \& Halder, P.K. (2016). Electrical energy conservation through human behaviour change: Perspective in Bangladesh. International Journal of Renewable Energy Research, 6(1), 1306-1315. Retrieved from https://www.ijrer.com/index.php/ijrer/article/view/3030

Khorasanizadeh, H., Honarpour, A., Park, M.S., Parkkinen, J., \& Parthiban, R. (2016). Adoption factors of cleaner product technology in a developing country: energy efficient lighting in Malaysia. Journal of Cleaner Production, 131, 97-106. doi.org/10.1016/j.jclepro.2016.05.070

Knapp, P., \& Beck, A.T. (2008). Cognitive therapy: Foundations, conceptual models, applications and research. Rev Bras Psiquiatr, 30 (Suppl. II), S54-64. doi: 10.1590/s151644462008000600002

Kock, N. (2015). Common method bias in PLS-SEM: A full collinearity assessment approach. International Journal of e-Collaboration, 11(4), 1-10. doi.org/10.4018/ijec.2015100101

Kollmuss, A., \& Agyeman, J. (2002). Mind the gap: Why do people act environmentally and what are the barriers to pro-environmental behaviour? Environmental Education Research, 8(3), 239-260. doi. org/10.1080/13504620220145401

Lee, M.C. (2010). Explaining and predicting users' continuance intention toward e-learning: an extension of the Expectation-Confirmation Model. Computers and Education, 54(2), 506-516. doi: 10.1016/j. compedu.2009.09.002

Lopez, A.G., \& Arango, M.A. (2008). Relationship among values, beliefs, norms and ecological behaviour. Psicothema, 20(4), 623-629. 
Lopez-Mosquera, N., \& Sanchez, M. (2012). Theory of planned behaviour and the value-belief-norm theory explaining willingness to pay for a suburban park. Journal of Environmental Management, 113, 251-262. doi: 10.1016/j.envman.2012.08.029

Mahlia, T.M.I., \& Saidur, R. (2010). A review on test procedure, energy efficiency standards and energy labels to room air conditioners and refrigerator-freezers. Renewable and Sustainable Energy Reviews, 14(7), 1888-1900.

Mills, J., Gaskell, P., Ingram, J., Dwyer, J., Reed, M., \& Short, C. (2017). Engaging farmers in environmental management through a better understanding of behaviour. Agriculture and Human Values, 34(2), 283299. doi: 10.1007/s10460-016-9705-4

Mishra, D., Akman, I. \& Mishra, A. (2014). Theory of reasoned action application for green information technology acceptance. Computers in Human Behaviour, 36, 29-40. doi.org/10.1016/j.chb.2014.03.030

Mishra, P., Jain, T., \& Motiani, M. (2017). Have green, pay more: An empirical investigation of consumer's attitude towards green packaging in an emerging economy. In: Sarkar R., Shaw A. (eds.). Essays on Sustainability and Management. (pp.125-150). Springer, Singapore.

Mohammad, J. Habib, F.Q., \& Alias, M.A. (2010). Job satisfaction and organizational citizenship behavior: An empirical study at higher learning institutions. Asian Academy of Management Journal, 16(2), 149-165.

Moon, S.G., Jeong, S.Y., \& Choi, Y. (2017). Moderating effects of trust on environmentally significant behaviour in Korea. Sustainability, 9(415), 1-19. doi.org/10.3390/su9030415

Moore, G.C., \& Benbasat, I. (1991). Development of an instrument to measure the perceptions of adopting an information technology innovation. Information Systems Research, 2(3), 192-222. doi. org/10.1287/isre.2.3.192

Neenan, M. (2018). Resilience as a Framework for Coaching: A Cognitive Behavioural Perspective. London: Routledge.

Nilsson, A., Wester, M., Lazarevic, D., \& Brandt, N. (2018). Smart homes, home energy management systems and real-time feedback: Lessons for influencing household energy consumption from a Swedish field study. Energy and Buildings, 179, 15-25. doi: 10.1016/j.enbuild.2018.08.026

Nordlund, A.M., \& Garvill, J. (2003). Effects of values, problem awareness and personal norm on willingness to reduce personal car use. Journal 
of Environment Psychology, 23(4), 339-347. doi.org/10.1016/S02724944(03)00037-9

O’Connor, R.E., Bord, R.J., \& Fisher, A. (1999). Risk perceptions, general environmental beliefs and willingness to address climate change. Risks Analysis, 19(3), 461-471. doi.org/10.1111/j.1539-6924.1999.tb00421.x

Paille, P., \& Mejia-Morelos, J.H. (2014). Antecedents of pro-environmental behaviours at work: The moderating influence of psychological contract breach. Journal of Environmental Psychology, 38, 124-131. doi. org/10.1016/j.jenvp.2014.01.004

Pallant, J. (2013). SPSS Survival Manual. United Kingdom: McGraw-Hill Education.

Palmgreen, P. (1984). Uses and gratifications: A theoretical perspective. Annals of the International Communication Association, 8(1) 20-55.

Paul, J., Modi, A., \& Patel, J. (2016). Predicting green product consumption using theory of planned behaviour and reasoned action. Journal of Retailing and Consumer Services, 29, 123-134. doi: 10.1016/j. jretconser.2015.11.006

Podsakoff, P.M., MacKenzie, S.B., Lee, J.Y., \& Podsakoff, N.P. (2003). Common method biases in behavioural research: A critical review of the literature and recommended remedies. Journal of Applied Psychology, 88(5), 879-903. doi: 10.1037/0021-9010.88.5.879

Poortvliet, P.M., Sanders, L., Weijma, J., \& Vries, J.R.D. (2018). Acceptance of new sanitation: The role of end-users' pro-environmental personal norms and risk and benefit perceptions. Water Research, 131, 90-99. doi: 10.1016/j.watres.2017.12.032

Preacher, K.J., \& Hayes, A.F. (2008). Asymptotic and resampling strategies for assessing and comparing indirect effects in multiple mediator models. Behavior Research Methods, 40(3), 879-891.

Previte, J., Rusell-Bennett, R., \& Parkinson, J. (2015). Shaping safe drinking cultures: Evoking positive emotion to promote moderate-drinking behavior. International Journal of Consumer Studies, 39(1), 12-24. doi. org/10.1111/ijcs. 12146

Rahmat, M.K., \& Au, W.K. (2013). Visual art education teachers' continuance intention to integrate ICT: A model development. Procedia - Social and Behavioural Sciences, 90, 356-364. doi: 10.1016/j. sbspro.2013.07.103

Raineri, N., \& Paille, P. (2016). Linking corporate policy and supervisory 
support with environmental citizenship behaviours: The role of employee environmental beliefs and commitment. Journal of Business Ethics, 137(1), 129-148. doi: 10.1007/s10551-015-2548-x

Ramayah, T. (2010). The role of voluntariness in distance education students' usage of a course website. The Turkish Online Journal of Educational Technology, 9(3), 96-105.

Ringle, C.M., Wende, S., \& Will, S. (2015). SmartPLS 3.0 (M3). Hamburg: University of Hamburg.

Rogers, E. (2003). Diffusion of Innovation. $5^{\text {th }}$ Edition. New York: The Free Press.

Rokeach, M. (1973). The Nature of Human Values. New York: The Free Press.

Sanchez, M., Mosquera, N.L., \& Lopez, F.L. (2016). Improving proenvironmental behaviours in Spain: The role of attitudes and sociodemographic and political factors. Journal of Environmental Policy and Planning, 18(1), 47-66. doi.org/10.1080/1523908X.2015.1046983

Schultz, P.W. (2000). New environmental theories: Empathizing with nature: The Effects of perspective taking on concern for environmental issues. Journal of Social Issues, 56(3), 391-406. doi.org/10.1111/00224537.00174

Schultz, P.W., \& Zelezny, L.C. (1999). Values as predictors of environmental attitudes: Evidence for consistency across cultures. Journal of Environmental Psychology, 19, 255-265.

Schwartz, S.H. (1994). Are there universal aspects in the structure and contents of human values? Journal of Social Issues, 50(4), 19-45. doi. org/10.1111/j.1540-4561.1994.tb01196.x

Schwartz, S.H. (1992). Universals in the content and structure of values theoretical advances and empirical tests in 20 countries. Advances in Experimental Social Psychology, 25, 1-65. doi.org/10.1016/S00652601(08)60281-6

Schwarz, M., \& Thompson, M. (1990). Divided We Stand: Redefining Politics, Technology and Social Choice. Philadelphia: University of Pennsylvania Press.

Siegrist, J. (1996). Adverse health effects of high-effort/ low-reward conditions. Journal of Occupational Health Psychology, 1, 27-41. doi. org/10.1037/1076-8998.1.1.27

Singh, D.P. (2011). Indian ecological consumer profile. Global Business 
Review, 12(3), 447-457. doi.org/10.1177/097215091101200307

Smyth, L., Mavor, K.I., \& Platow, M.J. (2017). Learning behaviour and learning outcomes: The roles of social influence and field of study. Social Psychology of Education: An International Journal, 20(1), 69-95.

Snyder, M., \& Omoto, A. (2008). Voluntariness: Social issues perspectives and social policy implications. Social Issues and Policy Review, 2(1), 1-36. doi.org/10.1111/j.17512409.2008.00009.x

Steg, L., Bolderdijk, J.W., Keizer, K. \& Perlaviciute, G. (2014). An integrated framework for encouraging pro-environmental behaviour: The role of values, situational factors and goals. Journal of Environmental Psychology, 38, 104-115. doi.org/10.1016/j.jenvp.2014.01.002

Steg, L. (2008). Promoting household energy conservation. Energy Policy, 36(12), 4449-4453. doi: 10.1016/j.enpol.2008.09.027

Steg, L. Dreijerink, L., \& Abrahamse, W. (2005). Factors influencing the acceptability of energy policies: A test of VBN theory. Journal of Environmental Psychology, 25, 415-425. doi: 10.1016/j. jenvp.2005.08.003

Stern, P.C. (2000). Toward a coherent theory of environmentally significant behavior. Journal of Social Issues, 56(3), 407-424. doi.org/10.1111/00224537.00175

Stern, P.C., \& Dietz, T. (1994). The value basis of environmental concern. Journal of Social Issues, 50, 65-84. doi.org/10.1111/j.1540-4560.1994. tb02420.x

Stern, P.C., Dietz, T., \& Kalof, L. (1993). Value orientations, gender and environmental concern. Environment and Behaviour, 25, 322-348. doi. org $/ 10.1177 / 0013916593255002$

Stern, P.C., Dietz, T., Abel, T.D., Guagnano, G.A., \& Kalof, L. (1999). A value-belief-norm theory of support for social movements: The case of environmentalism. Human Ecology Review, 6(2), 81-97.

Suki, N.M. (2013). Young consumer ecological behaviour: The effects of environmental knowledge, healthy food and healthy way of life with the moderation of gender and age. Management of Environment Quality: An International Journal, 24(6), 726-737. doi: 10.1108/MEQ-02-2013-0010

Susskind, A.M., Miller, V.D., \& Johnson, J.D. (1998). Downsizing and structural holes: Their impact on layoff survivors' perceptions of organizational chaos and openness to change. Communication Research, 25(1), 30-65. doi.org/10.1177\%2F009365098025001002 
Tan, C.S., Ooi, H.Y., \& Goh, Y.N. (2017). A moral extension of the theory of planned behaviour to predict consumers' purchase intention for energyefficient household appliances in Malaysia. Energy Policy, 107, 459-471. doi: 10.1016/j.enpol.2017.05.027

Teo, T. (2016). Modelling Facebook usage among university students in Thailand: The role of emotional attachment in an extended technology acceptance model. Interactive Learning Environment, 24(4), 745-757. doi.org/10.1080/10494820.2014.917110

Torelli, C.J., \& Kaikati, A.M. (2009). Values as predictors of judgments and behaviours: The role of abstract and concrete mindsets. Journal of Personality and Social Psychology, 96(1), 231-247.

Venkatesh, V., Morris, M.G., Davis, F.D., \& Davis, G.B. (2003). User acceptance of information technology: Toward a unified view. MIS Quarterly, 27, 425-478.

Walters, G.D. (2017). Effect of a brief cognitive behavioural intervention on criminal thinking and prison misconduct in male inmates: Variableoriented and person-oriented analyses. Criminal Behaviour and Mental Health, 27(5), 457-469. doi: 10.1002/cbm.2028

Wegner, D.M. (2002). The Illusion of Conscious Will. London: MIT Press. Wegner, D.M., \& Wheatley, T. (1999). Apparent mental causation: Sources of the experience of will. American Psychologist, 54(7), 480-492. doi. org/10.1037/0003-066X.54.7.480

Wu, D.W.L., DiGiacomo, A., \& Kingstone, A. (2013). Sustainable building promotes pro-environmental behaviour: An observational study on food disposal. PLoS ONE, 8, 1-4. doi: 10.1371/journal.pone.0053856

Yu, C.S. (2014). Factors affecting individuals to adopt mobile banking: Empirical evidence from the UTAUT model. Journal of Electronic Commerce Research, 13(2), 104-121.

Zhang, X., Liu, J., \& Zhao, K. (2018). Antecedents of citizens' environmental complaint intention in China: An empirical study based on norm activation model. Resources, Conservation and Recycling, 134, 121-128. doi.org/10.1016/j.resconrec.2018.03.003 
Appendix 1: Measurement Items

\begin{tabular}{|c|c|c|c|}
\hline Variable & Item & Measurement item & Source \\
\hline \multirow[t]{9}{*}{$\begin{array}{l}\text { Ecological } \\
\text { Behaviour }\end{array}$} & EB1 & $\begin{array}{l}\text { I guess I have never actually bought any } \\
\text { energy efficiency appliances because it } \\
\text { can save my electricity cost. (R) }\end{array}$ & $\begin{array}{l}\text { Fraj and } \\
\text { Martinez } \\
(2007)\end{array}$ \\
\hline & EB2 & $\begin{array}{l}\text { I keep track on how government is } \\
\text { handling the energy efficiency issues. }\end{array}$ & \\
\hline & EB3 & $\begin{array}{l}\text { I have communicated with other users } \\
\text { to find out about energy efficiency } \\
\text { appliances. }\end{array}$ & \\
\hline & EB4 & $\begin{array}{l}\text { I make a special effort to buy energy } \\
\text { efficiency appliances. }\end{array}$ & \\
\hline & EB5 & $\begin{array}{l}\text { I have attended an event that } \\
\text { specifically concerned with bettering the } \\
\text { environment. }\end{array}$ & \\
\hline & EB6 & $\begin{array}{l}\text { I have switched to use energy efficiency } \\
\text { appliances for ecological reasons. }\end{array}$ & \\
\hline & EB7 & $\begin{array}{l}\text { I have never joined a clean-up drive (e.g. } \\
\text { gotong-royong). (R) }\end{array}$ & \\
\hline & EB8 & $\begin{array}{l}\text { I have never attended a meeting related } \\
\text { to ecology. }(\mathrm{R})\end{array}$ & \\
\hline & EB9 & $\begin{array}{l}\text { I read materials pertaining to ecological } \\
\text { issues. }\end{array}$ & \\
\hline \multirow[t]{6}{*}{$\begin{array}{l}\text { Ecological } \\
\text { Beliefs }\end{array}$} & EF1 & $\begin{array}{l}\text { It frightens me that the electricity } \\
\text { production process bringing negative } \\
\text { impacts to the environment. }\end{array}$ & Singh (2011) \\
\hline & EF2 & $\begin{array}{l}\text { It makes me angry that some people do } \\
\text { not care about conserving electricity. }\end{array}$ & \\
\hline & EF3 & $\begin{array}{l}\text { It makes me angry that industries are } \\
\text { causing the waste of electricity. }\end{array}$ & \\
\hline & EF4 & $\begin{array}{l}\text { I am open to the idea of energy } \\
\text { conservation in improving the } \\
\text { environmental quality. }\end{array}$ & \\
\hline & EF5 & $\begin{array}{l}\text { I am concerned about the usage of } \\
\text { electrical energy in my city. }\end{array}$ & \\
\hline & EF6 & $\begin{array}{l}\text { I rarely worry about the effects of } \\
\text { excessive usage of electrical energy on } \\
\text { me and my family. (R) }\end{array}$ & \\
\hline
\end{tabular}




\begin{tabular}{|c|c|c|c|}
\hline Variable & Item & Measurement item & Source \\
\hline \multirow[t]{3}{*}{$\begin{array}{l}\text { Social } \\
\text { Influences }\end{array}$} & SI1 & $\begin{array}{l}\text { People who are important to me think I } \\
\text { should use energy efficiency appliances. }\end{array}$ & $\begin{array}{l}\text { Venkatesh et } \\
\text { al. }(2003)\end{array}$ \\
\hline & SI2 & $\begin{array}{l}\text { People who influence my behaviour } \\
\text { think that I should use energy efficiency } \\
\text { appliances. }\end{array}$ & \\
\hline & SI3 & $\begin{array}{l}\text { People who opinions that I value prefer } \\
\text { that I use energy efficiency appliances. }\end{array}$ & \\
\hline \multirow[t]{4}{*}{$\begin{array}{l}\text { Facilitating } \\
\text { Conditions }\end{array}$} & $\mathrm{FC} 1$ & $\begin{array}{l}\text { I have the resources (e.g. money) } \\
\text { necessary to purchase energy efficiency } \\
\text { appliances. }\end{array}$ & $\begin{array}{l}\text { Venkatesh et } \\
\text { al. (2003) }\end{array}$ \\
\hline & $\mathrm{FC} 2$ & $\begin{array}{l}\text { I have the necessary knowledge to use } \\
\text { energy efficiency appliances. }\end{array}$ & \\
\hline & FC3 & $\begin{array}{l}\text { The use of energy efficiency appliances } \\
\text { is compatible with other technologies } \\
\text { that I use. }\end{array}$ & \\
\hline & $\mathrm{FC} 4$ & $\begin{array}{l}\text { I can get help from others when I have } \\
\text { difficulties using energy efficiency } \\
\text { appliances. }\end{array}$ & \\
\hline \multirow[t]{4}{*}{$\begin{array}{l}\text { Ecoaltruistic } \\
\text { Values }\end{array}$} & EAV1 & $\begin{array}{l}\text { All natural resources have the right to } \\
\text { exist. }\end{array}$ & $\begin{array}{l}\text { Kaiser et al. } \\
(1999)\end{array}$ \\
\hline & EAV2 & All natural resources are precious. & \\
\hline & EAV3 & All natural resources must be conserved. & \\
\hline & EAV4 & $\begin{array}{l}\text { In general, extensive extraction of natural } \\
\text { resources should be forbidden. }\end{array}$ & \\
\hline \multirow[t]{6}{*}{$\begin{array}{l}\text { Openness to } \\
\text { Change }\end{array}$} & OTC1 & $\begin{array}{l}\text { I would consider myself 'open' to the } \\
\text { implementation of energy efficiency/ } \\
\text { saving feature appliances. }\end{array}$ & $\begin{array}{l}\text { Susskind et al. } \\
\text { (1998) }\end{array}$ \\
\hline & OTC2 & $\begin{array}{l}\text { Right now, I am somewhat resistant to } \\
\text { use energy efficiency/saving appliances. }\end{array}$ & \\
\hline & OTC3 & $\begin{array}{l}\text { I am quite reluctant to consider } \\
\text { changing to use energy efficiency/saving } \\
\text { appliances. }\end{array}$ & \\
\hline & OTC4 & $\begin{array}{l}\text { I think the usage of the energy efficiency/ } \\
\text { saving feature appliances positively } \\
\text { affect my life style. }\end{array}$ & \\
\hline & OTC5 & $\begin{array}{l}\text { From my perspective, the use of energy } \\
\text { efficiency/saving appliances are for the } \\
\text { betterment. }\end{array}$ & \\
\hline & OTC6 & $\begin{array}{l}\text { The changes as a result of using energy } \\
\text { efficiency/saving appliances positively } \\
\text { affect my life pattern. }\end{array}$ & \\
\hline
\end{tabular}


100 Sai-Keong Chan, Farzana Quoquab \& Rohaida Basiruddin

\begin{tabular}{cclc}
\hline Variable & Item & \multicolumn{1}{c}{ Measurement item } & \multicolumn{1}{c}{ Source } \\
\hline Voluntariness & VL1 & $\begin{array}{l}\text { Although it can save electricity costs, } \\
\text { using energy efficiency/saving appliances } \\
\text { are not compulsory by the local authority. }\end{array}$ & $\begin{array}{l}\text { Venkatesh et } \\
\text { al. (2003) }\end{array}$ \\
VL2 & $\begin{array}{l}\text { My use of energy efficiency/saving } \\
\text { appliances in my home and workplace is } \\
\text { voluntary. } \\
\text { My friends and family expect me to use } \\
\text { the energy efficiency/saving appliances. }\end{array}$ \\
\hline
\end{tabular}

